\title{
Effects of different vegetation types on burnt soil properties and microbial communities
}

\author{
Speranza C. Panico ${ }^{\mathrm{A}}$, Maria T. Ceccherini ${ }^{\mathrm{B}}$, Valeria Memoli ${ }^{\mathrm{A}}$, Giulia Maisto ${ }^{\mathrm{A}}$, \\ Giacomo Pietramellara ${ }^{B}$, Rossella Barile ${ }^{C}$ and Anna De Marco (iD) D,E \\ A Department of Biology, University of Naples Federico II, Via Cinthia, 80126 Naples, Italy. \\ ${ }^{B}$ DAGRI - Department of Agriculture, Food, Environment and Forestry University of Florence, \\ P. le delle Cascine, 28-50144 Firenze, Italy. \\ CVesuvius National Park, Via Palazzo del Principe c/o Castello Mediceo, Ottaviano, \\ 80044 Naples, Italy. \\ DDepartment of Pharmacy, University of Naples Federico II, Via Montesano 49, 80131 Naples, \\ Italy. \\ ${ }^{\mathrm{E}}$ Corresponding author. E-mail: ademarco@unina.it
}

\begin{abstract}
The intensive wildfires recurring in the Mediterranean area modify soil physico-chemical properties, in turn inducing changes in soil microbial abundance and activity. Soils were sampled from burnt and adjacent unburnt sites within Vesuvius National Park 1 year after a large wildfire occurred in summer 2017. The aims of the present study were to evaluate the effects of fires on soil characteristics and to investigate whether different plant types contribute to mitigating or enhancing these effects. The results showed lower organic matter and water content and a higher $\mathrm{C} / \mathrm{N}$ ratio in burnt than in unburnt soils. In particular, this trend was the same for all the plant types investigated, with the exception of soils covered by black locust tree and holm oak, which showed a higher $\mathrm{C} / \mathrm{N}$ ratio in unburnt than in burnt soils. In soils covered by holm oaks, a shift in the bacterial and fungal fractions occurred between burnt and unburnt soils, whereas the amount of ammonia oxidisers was notably higher in burnt than in unburnt soils covered by black locusts; the highest $\mathrm{N}$ concentration was also measured in burnt soils covered by black locusts. The burnt soils showed a lower metabolic quotient and a higher rate of organic carbon mineralisation compared with unburnt soils, and this trend was particularly evident in soils under herbaceous plants. The findings suggest that soils covered by herbaceous species are more sensitive to fire effects and less able to restore their functionality compared with soils covered by trees.
\end{abstract}

Additional keywords: black locust, fungal/bacterial/ammonia oxiders sequences, herbaceous species, holm oak, microbial activity, organic matter, wildfire.

Received 3 June 2019, accepted 28 January 2020, published online 17 February 2020

\section{Introduction}

Approximately 65000 fires occur every year in Europe, and more than $85 \%$ of these fires occur in Mediterranean regions (i.e. southern France, Greece, Italy, Portugal and Spain), especially during summer (July-September), when there is drought, high temperatures, low air humidity and scarce rainfall (San-Miguel-Ayanz and Camia 2010). Additionally, in these areas, most wildfires are of anthropogenic origin and affect a wide range of soil surfaces, threatening soil biodiversity and function as well as vegetation resources (Ganteaume et al. 2013; Rodríguez et al. 2017).

Mediterranean ecosystems are characterised by a wide heterogeneity of plant types ranging from pine and holm oak (Quercus ilex) forests to shrublands and grasslands. Recently, invasive species such as black locust tree (Robinia pseudoacacia) and oleander have become widespread, and play a fundamental role in modifying the relationships among native species, altering the functionality of the whole community above and below ground (De Marco et al. 2013; Wolfe and Klironomos 2005).

For instance, herbaceous species produce less biomass and have less potential carbon storage compared with shrubs and trees (Virzo De Santo et al. 2002; De Marco et al. 2008). Moreover, the high heterogeneity of leaf traits (i.e. sclerophylls, which have hard and leathery leaves, and herbs, which have soft leaves) leads to the accumulation of litter with different qualities, influencing the decomposition rate, organic matter turnover and soil carbon sequestration (Vesterdal et al. 2012). The chemical and morphological complexity of litter reflects soil microbial biodiversity and activity, and usually increases from herbs to trees (Rutigliano et al. 2007).

Within this framework, multiple and diversified effects of wildfires act on this heterogeneous environment, often inducing 
conflicting and unpredictable responses. Fire, both natural and human-caused, has played a large role in shaping Mediterranean ecoregions (Gil-Tena et al. 2016), and in relation to different plant types, significantly affects soil physico-chemical properties such as $\mathrm{pH}$, organic matter and water content, and nutrient cycles (Raison et al. 2009; Gómez-Rey et al. 2013). Wildfires typically result in the reduction of fuel and soil nutrient pool sizes and increase soil nutrient turnover rates, inducing, for instance, faster mineralisation and a higher potential loss of carbon and nitrogen from soils covered by herbaceous plants compared with soil covered by trees (De Marco et al. 2008). Moreover, after fires, the complexity of soil organic matter can increase owing to the production of charcoal, which has high resistance to degradation, enhancing soil water retention (González-Pérez et al. 2004); by contrast, the destruction of organic matter by fire reduces soil permeability and water retention (Martin and Moody 2001).

These changes in soil abiotic characteristics affect the abundance, diversity and activity of soil microorganisms (Certini 2005; Bouchez et al. 2016; Panico et al. 2018). In particular, soil microbial biomass and diversity has been reported to decline (Mabuhay et al. 2006), increase (D'Ascoli et al. 2005) or not change significantly between unburnt and burnt soils (Goberna et al. 2012). The lack of unified responses of the soil microbial community to wildfires poses a challenge to researchers seeking to implement the current knowledge, especially in Mediterranean areas, where wildfires are frequent and severe (Arias et al. 2005; Thom and Seidi 2016).

Because wildfires are unpredictable, study approaches based on a comparison between unburnt and burnt sites in the same area are not always applicable, although they could potentially be useful to better understand the effects of wildfires on soil characteristics. In the present study, this approach was applied inside Vesuvius National Park, where a large wildfire occurred in summer 2017. The aims of the research were to evaluate the effects of wildfires on soil physico-chemical and biological characteristics by comparing burnt and adjacent unburnt soils covered by the same plant typology, and to highlight whether different plant types contribute to mitigating or enhancing the effects of wildfires on soil characteristics.

The research was carried out within three areas dominated by different plant types: one grassland with a prevalence of herbaceous species and two forests where black locusts or holm oaks were dominant. Specifically, the hypotheses were as follows: (1) the plant types affected the soil physico-chemical and biological characteristics; (2) within the same plant type, there were differences between burnt and unburnt soil; and (3) specific fire effects on soil were related to the distinct plant type.

\section{Materials and methods}

Study area and soil sampling

The study area is located inside Vesuvius National Park $\left(40^{\circ} 52^{\prime} 21^{\prime \prime} 36 \mathrm{~N} ; 14^{\circ} 26^{\prime} 13^{\prime \prime} 20 \mathrm{E}\right.$; Campania, Italy), where in June 2017, a wildfire occurred, causing the loss of more than $50 \%$ ( $\sim 3000 \mathrm{ha}$ ) of the existing plant cover (www.forbes.com/ sites/davidbressan/2017/07/19; www.earth.esa.int/web/earthwatching/environmental-hazards/content). The park's flora is typically Mediterranean, mainly populated by herbaceous
Table 1. Sampling sites in Vesuvius National Park, Italy The selected areas showed different vegetation types: herbaceous $(\mathrm{H})$ grasses, mosses and lichens; black locust (BL); holm oak (HO); and geographical coordinates. In each area, soil has been sampled in burnt (B) and unburnt (U) sites

\begin{tabular}{lcc}
\hline Vegetation cover & Geographical coordinates & Site type \\
\hline Herbaceous (H) & $40^{\circ} 82^{\prime} 30^{\prime \prime} \mathrm{N} 14^{\circ} 39^{\prime} 96^{\prime \prime} \mathrm{E}$ & $\mathrm{B} / \mathrm{U}$ \\
Herbaceous (H) & $40^{\circ} 83^{\prime} 07^{\prime \prime} \mathrm{N} 14^{\circ} 25^{\prime} 28^{\prime \prime} \mathrm{E}$ & $\mathrm{B} / \mathrm{U}$ \\
Herbaceous (H) & $40^{\circ} 81^{\prime} 81^{\prime \prime} \mathrm{N} 14^{\circ} 43^{\prime} 50^{\prime \prime} \mathrm{E}$ & $\mathrm{B} / \mathrm{U}$ \\
Herbaceous (H) & $40^{\circ} 82^{\prime} 17^{\prime \prime} \mathrm{N} 14^{\circ} 43^{\prime} 57^{\prime \prime} \mathrm{E}$ & $\mathrm{B} / \mathrm{U}$ \\
Black locust (BL) & $40^{\circ} 81^{\prime} 20^{\prime \prime} \mathrm{N} 14^{\circ} 44^{\prime} 07^{\prime \prime} \mathrm{E}$ & $\mathrm{B} / \mathrm{U}$ \\
Black locust (BL) & $40^{\circ} 80^{\prime} 88^{\prime \prime} \mathrm{N} 14^{\circ} 43^{\prime} 92^{\prime \prime} \mathrm{E}$ & $\mathrm{B} / \mathrm{U}$ \\
Black locust (BL) & $40^{\circ} 82^{\prime} 36^{\prime \prime} \mathrm{N} 14^{\circ} 43^{\prime} 53^{\prime \prime} \mathrm{E}$ & $\mathrm{B} / \mathrm{U}$ \\
Black locust (BL) & $40^{\circ} 82^{\prime} 13^{\prime \prime} \mathrm{N} 14^{\circ} 43^{\prime} 62^{\prime \prime} \mathrm{E}$ & $\mathrm{B} / \mathrm{U}$ \\
Holm oak (HO) & $40^{\circ} 80^{\prime} 72^{\prime \prime} \mathrm{N} 14^{\circ} 43^{\prime} 46^{\prime \prime} \mathrm{E}$ & $\mathrm{B} / \mathrm{U}$ \\
Holm oak (HO) & $40^{\circ} 80^{\prime} 88^{\prime \prime} \mathrm{N} 14^{\circ} 43^{\prime} 92^{\prime \prime} \mathrm{E}$ & $\mathrm{B} / \mathrm{U}$ \\
Holm oak (HO) & $40^{\circ} 81^{\prime} 67^{\prime \prime} \mathrm{N} 14^{\circ} 40^{\prime} 86^{\prime \prime} \mathrm{E}$ & $\mathrm{B} / \mathrm{U}$ \\
Holm oak (HO) & $40^{\circ} 81^{\prime} 03^{\prime \prime} \mathrm{N} 14^{\circ} 40^{\prime} 86^{\prime \prime} \mathrm{E}$ & $\mathrm{B} / \mathrm{U}$ \\
\hline
\end{tabular}

species (mosses, lichens, red valerian, rock helichrysum, sage and many species of grasses), scarce shrubs (myrtle, laurel, wayfarer, brambles and brooms) and forest areas where holm oaks are dominant and some pine species (scots pine, black pine, maritime pine and stone pine) are present (Memoli et al. 2018). Additionally, black locusts, an invasive species used since 1912 for afforestation and the stabilisation of volcanic substrates (De Marco et al. 2013), are widespread in many areas of Vesuvius National Park.

In 2017, the wildfire did not totally attack the whole area of the park, leaving burnt and unburnt areas inside each plant cover typology. The burnt sites were affected by severe surface fire, showing a completely consumed forest floor, as described by Level 4 of the soil burn severity index (SBS), whereas the unburnt sites belonged to Level 0 , because they did not show evidence of fire (Vega et al. 2013). In June 2018, 1 year after the wildfire, lepti-vitric andosols (Di Gennaro 2002) were sampled after litter removal in three areas with different plant cover. The first area was covered by herbaceous plants $(\mathrm{H})$, and the second and the third were covered by trees, black locust (BL) and holm oak (HO) respectively (Table 1$)$. The unburnt sites dominated by herbaceous species were covered by red valerian (Centranthus ruber), rock helichrysum (Helichrysum litoreum), sage (Artemisia campestris), French sorrel (Rumex scutatus), Spanish broom (Spartium junceum), Scotch broom (Cytisus scoparius), wayfarer (Viburnum lantara), laurustinus (V. tinus), Cistus sp. and several mosses, lichens and grasses. The burnt sites were mainly covered by vegetation not killed by fire, resprouting shrubs and plants according to the pre-existing vegetation type at the time of sampling (1 year after the fire).

For each plant typology, four sampling areas were selected, and in each area, soil was sampled in burnt (B) and adjacent unburnt $(\mathrm{U})$ sites (Table 1). Soil $(0-10 \mathrm{~cm})$ sampling was carried out after a month without rain; the samples were collected in sterile flasks and transported on ice to the laboratory, where they were sieved (2-mm mesh size). A portion of the soil was kept at room temperature to perform physico-chemical analyses, 
another portion was kept at $4{ }^{\circ} \mathrm{C}$ to evaluate the microbial activities and the last portion was kept at $-20^{\circ} \mathrm{C}$ to perform molecular analyses.

\section{Soil physico-chemical analyses}

For the sieved soil samples, we measured the water content (WC), $\mathrm{pH}$, organic matter (OM) content and carbon (C) and nitrogen $(\mathrm{N})$ concentrations. WC was determined by gravimetrically drying fresh soil at $105^{\circ} \mathrm{C}$ until constant weight. $\mathrm{pH}$ was measured in a soil : distilled water $(1: 2.5=\mathrm{v}: \mathrm{v})$ suspension by an electrometric method. To calculate the OM content, the organic carbon $\left(\mathrm{C}_{\mathrm{org}}\right)$ was determined by gas chromatography (carbon, nitrogen, sulfur (CNS) analyser, Flash 112 Series EA, Thermo Finnigan, Milan, Italy) in soil samples previously treated with hydrogen chloride $(\mathrm{HCl} ; 10 \%)$ to exclude carbonates. Then, the $\mathrm{OM}$ content was obtained by multiplying $\mathrm{C}_{\text {org }}$ by 1.724 (Pribyl 2010). The total $\mathrm{C}$ and $\mathrm{N}$ concentrations were evaluated in oven-dried $\left(105^{\circ} \mathrm{C}\right.$, until constant weight $)$ and ground (Analysette Spartan 3 Pulverisette 0, Fritsch, IdarOberstein, Germany) soil samples by gas chromatography. Then, the $\mathrm{C} / \mathrm{N}$ ratios were calculated. The physico-chemical analyses were performed in triplicate.

\section{Soil biological activity}

Microbial activity was estimated as the potential respiration according to Anderson and Domsch (1978). To evaluate microbial biomass $\left(\mathrm{C}_{\text {mic }}\right)$ and respiration (Resp), the $\mathrm{CO}_{2}$ evolution from samples at $55 \%$ water-holding capacity was measured by $\mathrm{NaOH}$ absorption followed by two-phase titration with $\mathrm{HCl}$ (Froment 1972) after incubation at $25^{\circ} \mathrm{C}$ in tight containers for 5 and 10 days respectively. Microbial carbon was evaluated by substrate-induced respiration (SIR) in response to the addition of glucose $(75 \mathrm{~mm})$, an easily mineralisable substrate (Degens et al. 2000). The magnitude of the respiratory response was converted to $\mathrm{mg}$ of microbial biomass carbon using the conversion factor introduced by Sparling (1995). The potential respiration of soil samples was estimated as the $\mathrm{CO}_{2}$ evolution after adding $3 \mathrm{~mL}$ distilled water to $3 \mathrm{~g}$ of sample. The results obtained from the biological analyses were used to calculate two indices: the metabolic quotient $\left(\mathrm{qCO}_{2}\right)$, i.e. the degree of activity of the microbial biomass (Insam and Haselwandter 1989); and the coefficient of endogenous mineralisation (CEM), i.e. the rate of organic carbon mineralisation (Rutigliano et al. 2002). $\mathrm{qCO}_{2}$ was calculated as the ratio between Resp $\left(\mathrm{C}-\mathrm{CO}_{2}\right)$ and $\mathrm{C}_{\text {mic }}$, whereas CEM was calculated as the ratio between $\operatorname{Resp}\left(\mathrm{C}-\mathrm{CO}_{2}\right)$ and $\mathrm{C}_{\text {org }}$. The microbial activities were analysed in quadruplicate.

\section{DNA extraction and quantitative PCR (polymerase chain reaction) analyses}

The application of molecular biological techniques based on DNA extraction from soil and subsequent specific gene PCR (polymerase chain reaction) amplification can reveal a population structure that is not apparent from classical cultivation studies (Nannipieri et al. 2003). In this work, we used soil DNA extraction and specific quantitative PCR (qPCR) to monitor the effects of intensive wildfires on the abundances of the bacterial and fungal communities, and on the sensitive ammonia-oxidising bacterial population involved in an important stage of the nitrogen cycle (Hastings et al. 1997).

Total soil DNA extraction was performed in triplicate using a FastPrep MP instrument and FastDNA SPIN Kit for Soil (MP Biomedicals, Eschwege, Germany) with modifications to the manufacturer's instructions according to Ceccherini et al. (2007). The DNA yield ( $\mu \mathrm{g}$ DNA g ${ }^{-1}$ soil) and purity were quantified spectrophotometrically (Picodrop, Hinxton, United Kingdom). The quality of total DNA was further assessed by agarose gel electrophoresis.

qPCR analyses were used to quantify the total bacterial $16 \mathrm{~S}$ rDNA gene, the total fungal 18S rDNA gene and the ammonia oxidising amoA gene in each soil DNA sample. The primer sets used and the qPCR cycling conditions for each primer set are shown in Table S1, available as Supplementary material to this paper. Each sample was assayed in triplicate (three technical replicates of 13 independent replicates) on a CFX96 Touch RealTime PCR detection system (Bio-Rad laboratories, Hercules, CA). Each $25 \mu \mathrm{L}$ qPCR assay contained $1 \times$ iTAQ UNIVERSYBR GREEN SMX 2500 mix (Bio-Rad Laboratories), $10 \mu \mathrm{m}$ each forward and reverse primers, $40 \mathrm{ng}$ of template DNA and sterile double-distilled $\mathrm{H}_{2} \mathrm{O}$ to reach the appropriate volume.

Nanograms of the target sequence were normalised to grams of dry soil; this assumption is appropriate in this study because relative (vs absolute) quantification was measured.

The total DNA, fungal (18S rDNA), bacterial (16S rDNA) and ammonia oxidiser (amoA gene) sequences were expressed as copy number per gram of dry mass of soil.

\section{Statistical analyses}

Data for the burnt and unburnt soils were reported as the median and mean values to estimate the central data tendency. The normality of the data distribution was assessed by the ShapiroWilks test. Paired $t$-tests were performed to evaluate the significance of differences between burnt and unburnt soils.

One-way analysis of variance (ANOVA) was performed to test the differences in soil characteristics among the three different vegetation types in both burnt and unburnt sites. ANOVAs were followed by post hoc Holm-Sidak tests.

All parameters were used in the standardised principal component analysis (PCA) to find the main factors affecting the soil physico-chemical and biological characteristics. Multivariate analysis of variance (MANOVA) was performed to test the relationships between the site distribution in the principal component (PC) space and vegetation cover and fire occurrence.

The statistical assays, performed by Systat_SigmaPlot_14.0 software (Jandel Scientific, San Jose, CA), were considered statistically significant at $P<0.05$. The PCA and MANOVA analyses were performed using the R 3.1.1 programming environment (R Core Team 2016) using the Vegan^ package.

\section{Results}

Physico-chemical and biological properties of burnt and unburnt soils

An overall evaluation of the statistically significant soil physicochemical property changes showed that $\mathrm{WC}$ and $\mathrm{OM}$ were higher ( $P<0.001$ and $P<0.05$ respectively) in unburnt than in burnt soils (Fig. 1a); by contrast, the $\mathrm{C} / \mathrm{N}$ ratio was higher 
(a)
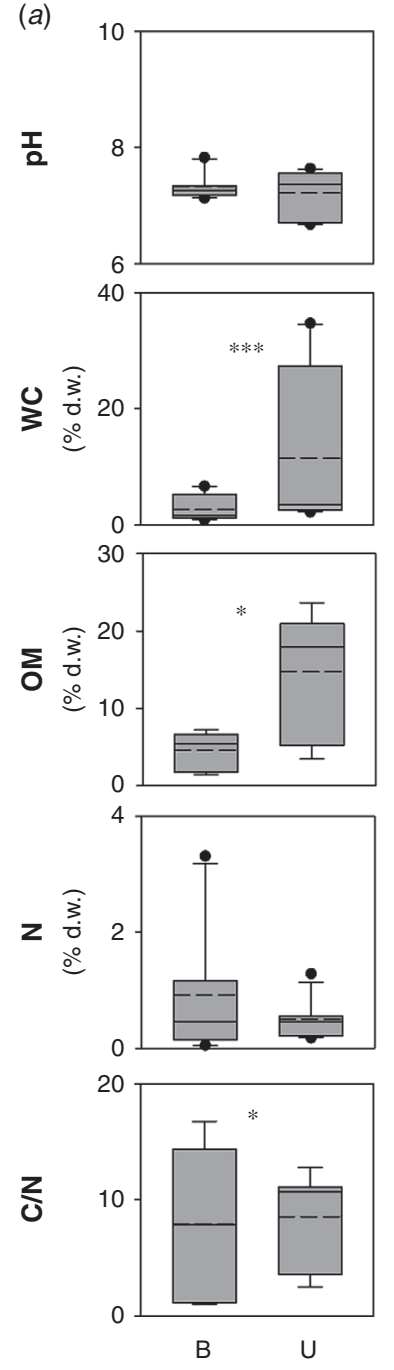

(b)
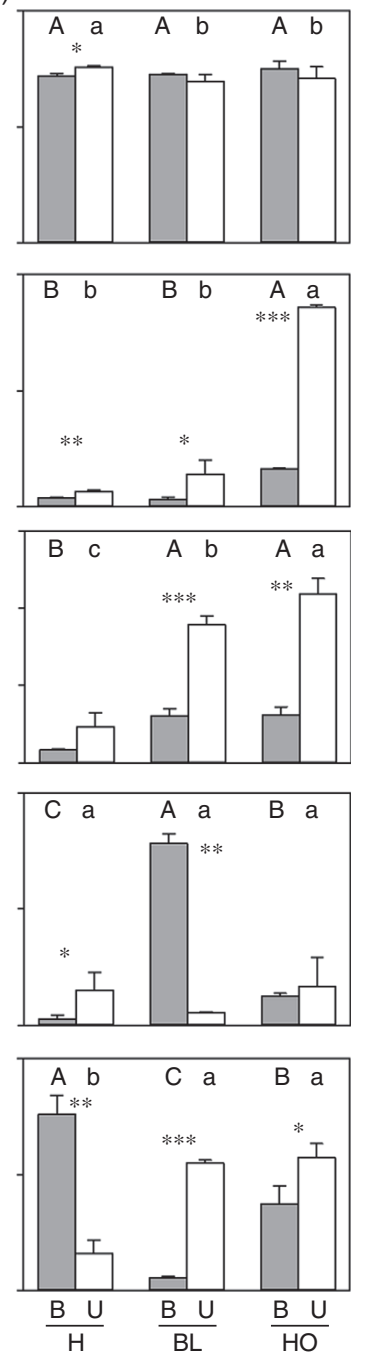

Fig. 1. Changes in soil $\mathrm{pH}$, water (WC), organic matter $(\mathrm{OM})$, nitrogen $(\mathrm{N})$ content and $\mathrm{C} / \mathrm{N}$ ratio in surface soil $(0-10 \mathrm{~cm})$ collected at burnt $(\mathrm{B})$ and unburnt (U) sites under different plant types (H, herbaceous; BL, black locust; $\mathrm{HO}$, holm oak). On the left, $\operatorname{panel}(a)$ shows a box plot of the values of the $\mathrm{B}$ and $\mathrm{U}$ soils. The boxes indicate the 25 th and 75 th percentiles, the continuous lines indicate the median values, the dashed lines indicate the mean values and the upper and lower whiskers indicate the maximum and minimum values of the dataset respectively. Panel $(b)$ shows the mean values \pm standard errors in $\mathrm{B}$ and $\mathrm{U}$ soils under $\mathrm{H}, \mathrm{BL}$ and $\mathrm{HO}$ cover. Different uppercase and lowercase letters indicate statistically significant differences among the three plant types in burnt and unburnt sites respectively (one-way ANOVA; $P<0.05$ ). The asterisks indicate statistically significant differences between $\mathrm{B}$ and $\mathrm{U}$ sites $(t$-test; $P<0.05)$.

$(P<0.05)$ in burnt soils (Fig. $1 a)$. In particular, according to the different plant types, soils covered by herbaceous plants showed a higher $\mathrm{pH}(P<0.05)$, WC content $(P<0.01)$ and $\mathrm{N}$ concentration $(P<0.05)$ in unburnt than in burnt conditions, whereas the $\mathrm{C} / \mathrm{N}$ ratio was higher $(P<0.01)$ in burnt soils (Fig. $1 b)$; in soils covered by black locust and holm oak, WC $(P<0.05$ and $P<0.001$ respectively $), \mathrm{OM}(P<0.001$ and $P<0.01$ respectively $)$ and $\mathrm{C} / \mathrm{N}(P<0.001$ and $P<0.05$

(a)
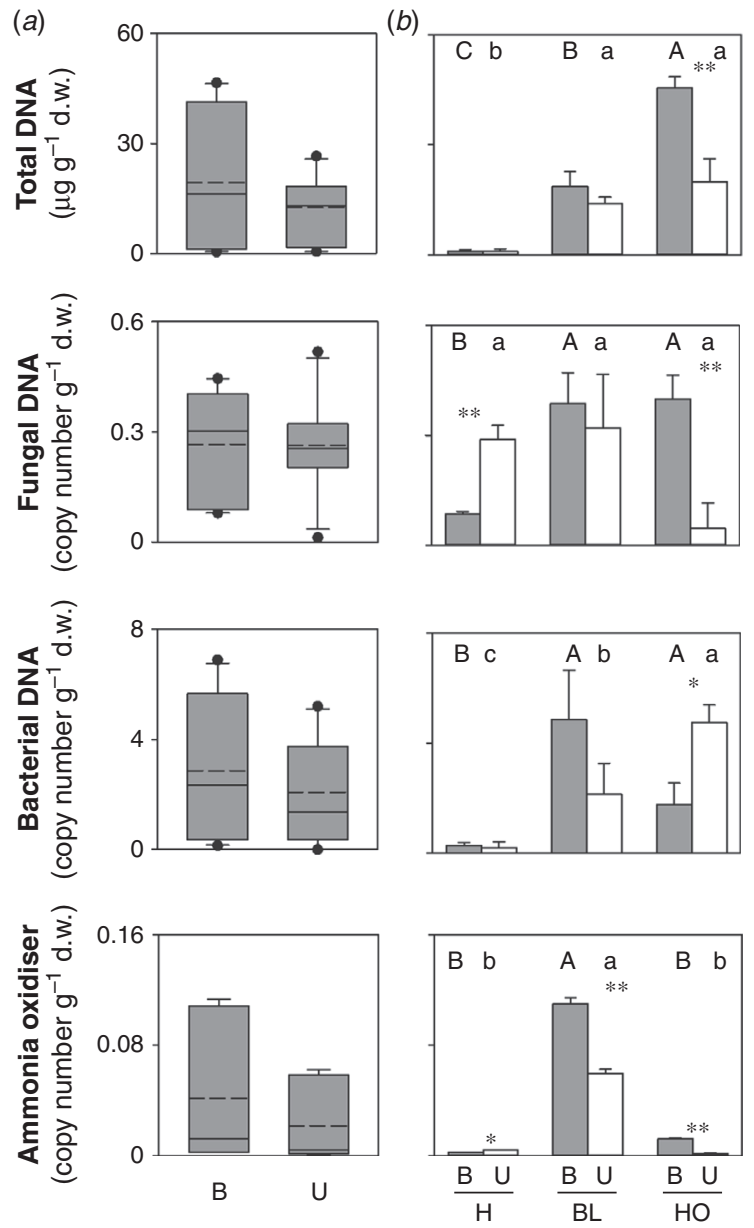

Fig. 2. Changes in soil total DNA, fungal DNA, bacterial DNA and ammonia oxidiser abundance in surface soil $(0-10 \mathrm{~cm})$ collected at burnt (B) and unburnt $(\mathrm{U})$ sites under different plant types ( $\mathrm{H}$, herbaceous; BL, black locust; HO, holm oak). On the left, panel $(a)$ shows a box plot of the values of the $\mathrm{B}$ and $\mathrm{U}$ soils. The boxes indicate the 25 th and 75 th percentiles, the continuous lines indicate the median values, the dashed lines indicate the mean values and the upper and lower whiskers indicate the maximum and minimum values of the dataset respectively. Panel $(b)$ shows the mean values \pm standard errors in $\mathrm{B}$ and $\mathrm{U}$ soils under $\mathrm{H}, \mathrm{BL}$ and $\mathrm{HO}$ cover. Different uppercase and lowercase letters indicate statistically significant differences among the three plant types in burnt and unburnt sites respectively (one-way ANOVA; $P<0.05$ ). The asterisks indicate statistically significant differences between $\mathrm{B}$ and $\mathrm{U}$ sites $(t$-test; $P<0.05)$.

respectively) were higher in unburnt than in burnt conditions, and only in soils covered by black locust was the N concentration higher $(P<0.01)$ in burnt than in unburnt soils (Fig. 1b).

Taking into account all the sites, the total DNA, fungal (18S rDNA), bacterial (16S rDNA) and ammonia oxidiser (amoA gene) sequence amounts showed similar mean values in burnt and unburnt soils (Fig. 2a). However, according to the different plant types, numerous statistically significant differences were found for these characteristics (Fig. 2b). In herbaceous soils, fungal DNA and ammonia oxidisers were more abundant ( $P<0.01$ and $P<0.05$ respectively) in unburnt than in burnt conditions (Fig. $2 b$ ); in soils covered by black locust, ammonia 


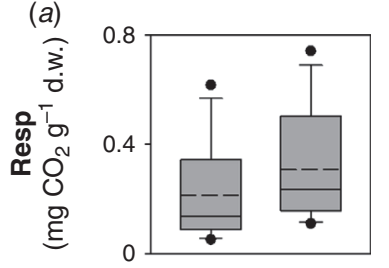

(b)
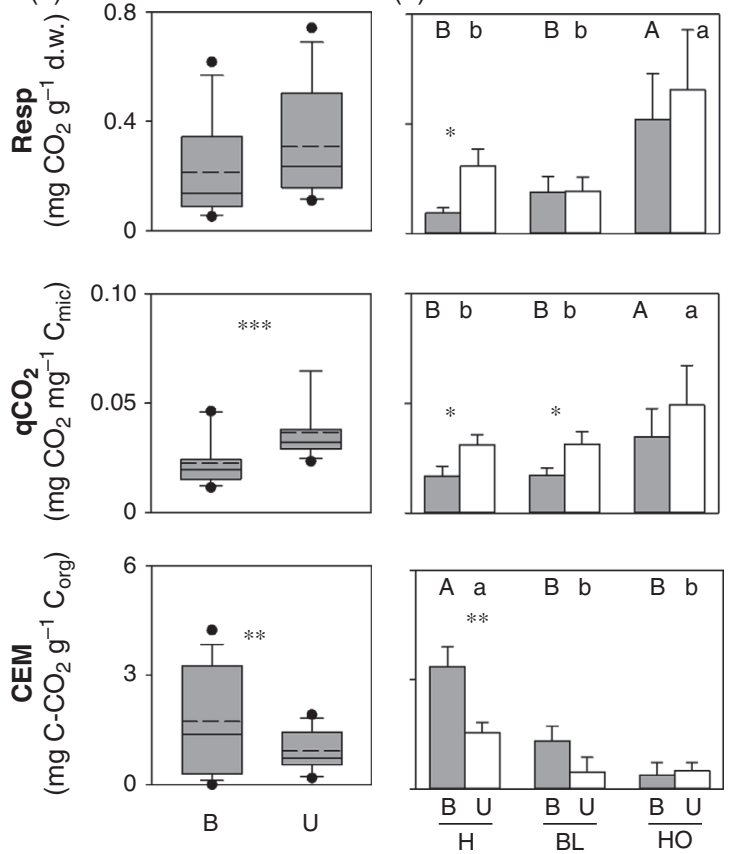

Fig. 3. Changes in soil microbial respiration (Resp), metabolic quotient $\left(\mathrm{qCO}_{2}\right)$ and coefficient of endogenous mineralisation (CEM) in surface soil $(0-10 \mathrm{~cm})$ collected at burnt $(\mathrm{B})$ and unburnt $(\mathrm{U})$ sites under different plant types ( $\mathrm{H}$, herbaceous; BL, black locust; HO, holm oak). On the left, panel (a) shows a box plot of the values of the $\mathrm{B}$ and $\mathrm{U}$ soils. The boxes indicate the 25 th and 75 th percentiles, the continuous lines indicate the median values, the dashed lines indicate the mean values and the upper and lower whiskers indicate the maximum and minimum values of the dataset respectively. Panel (b) shows the mean values \pm standard errors in $\mathrm{B}$ and $\mathrm{U}$ soils under $\mathrm{H}, \mathrm{BL}$ and HO cover. Different uppercase and lowercase letters indicate statistically significant differences among the three plant types in burnt and unburnt sites respectively (one-way ANOVA; $P<0.05$ ). The asterisks indicate statistically significant differences between $\mathrm{B}$ and $\mathrm{U}$ sites $(t$-test; $P<0.05)$.

oxidisers were more abundant $(P<0.01)$ in burnt than in unburnt conditions (Fig. 2b); finally, in soils covered by holm oak, total and fungal DNA and ammonia oxidisers were more abundant $(P<0.01)$ in burnt than in unburnt conditions, whereas bacterial DNA was more abundant $(P<0.05)$ in unburnt conditions (Fig. $2 b)$. Soil $\mathrm{qCO}_{2}$ was statistically higher $(P<0.01)$ in unburnt than in burnt soils (Fig. $3 a$ ); by contrast, CEM was significantly higher $(P<0.01)$ in burnt soils (Fig. $3 a)$. In soils covered by herbaceous species, Resp and $\mathrm{qCO}_{2}$ were statistically higher $(P<0.05)$ in unburnt than in burnt conditions; conversely, CEM was higher $(P<0.01)$ in burnt conditions (Fig. $3 b)$. In soils covered by black locust, $\mathrm{qCO}_{2}$ was statistically higher $(P<0.05)$ in unburnt than in burnt soils (Fig. $3 b$ ).

\section{Physico-chemical and biological properties among different plant types}

At the unburnt sites, numerous statistically significant soil physico-chemical variations in relation to plant type were highlighted. In particular, $\mathrm{pH}$ was higher $(P<0.05)$ in soils covered by herbaceous plants than in those collected under trees (Fig. 1b); WC and OM showed higher values in soils covered by holm oak $(P<0.001)$ (Fig. $1 b)$; and finally, $\mathrm{C} / \mathrm{N}$ values were lower $(P<0.01)$ in soils covered by herbaceous plants (Fig. $1 b)$. The total DNA amount was higher $(P<0.001)$ in soils covered by black locust and holm oak (Fig. $2 b$ ). Additionally, bacterial DNA was statistically higher $(P<0.05)$ in soils covered by holm oak (Fig. $2 b$ ), and ammonia oxidisers were higher $(P<0.001)$ in soils covered by black locust (Fig. $2 b$ ). Considering the biological activities, Resp and $\mathrm{qCO}_{2}$ showed higher $(P<0.05)$ values in soils covered by holm oak, whereas CEM was statistically higher $(P<0.05)$ in soils covered by herbaceous plants (Fig. $3 b)$.

At the burnt sites, according to the different soil plant types, numerous statistically significant differences were found. In particular, WC was higher $(P<0.01)$ in soils covered by holm oak (Fig. 1b); OM values were higher $(P<0.001)$ in soils covered by black locust and holm oak than in soils covered by herbaceous plants (Fig. 1b); and the $\mathrm{N}$ concentrations and $\mathrm{C} / \mathrm{N}$ ratios were higher $(P<0.001)$ and lower $(P<0.001)$, respectively, in soils covered by black locust (Fig. $1 b)$. Total DNA was higher $(P<0.001)$ in soils covered by holm oak (Fig. $2 b)$; fungal and bacterial DNA values were higher $(P<0.01$ and $P<0.05$ respectively) in soils covered by black locust and holm oak than in soils covered by herbaceous plants (Fig. $2 b$ ); and ammonia oxidisers were higher $(P<0.001)$ in soils covered by black locust (Fig. 2b). Considering the biological activities, soil Resp and $\mathrm{qCO}_{2}$ showed higher $(P<0.05)$ values in soils covered by holm oak, whereas CEM was statistically higher $(P<0.01)$ in soils covered by herbaceous plants (Fig. $3 b$ ).

\section{Principal component analysis (PCA)}

The PCA highlighted that the first two dimensions accounted for $59 \%$ of the total variance in the dataset (Fig. 4). The investigated soil characteristics were clearly separated in the PC space (Fig. 4): total, fungal and bacterial DNA, ammonia oxidisers and soil $\mathrm{N}$ concentration were located in the first quadrant; OM, WC, Resp and $\mathrm{qCO}_{2}$ were located in the second quadrant; $\mathrm{C} / \mathrm{N}$ and $\mathrm{CEM}$ were located in the third quadrant; and $\mathrm{pH}$ was located in the fourth quadrant. According to the MANOVA test, the site distribution in the PC space was related to both vegetation cover $(P<0.001)$ and fire occurrence $(P<0.05)$. In particular, along the first axis, B (burnt) and $U$ (unburnt) soils covered by herbaceous plants were clustered in the negative direction, whereas $\mathrm{B}$ and $\mathrm{U}$ soils covered by black locust and holm oak were clustered in the positive direction (Fig. 4). The first axis of the PCA was positively $(P<0.05)$ correlated with $\mathrm{OM}$, WC, total and bacterial DNA, Resp, $\mathrm{qCO}_{2}$ and CEM. Along the second axis, both burnt and unburnt sites covered by holm oak and herbaceous plants were mainly clustered in the negative direction, whereas soils covered by black locust were clustered mainly in the positive direction (Fig. 4). The second axis of the PCA was positively $(P<0.05)$ correlated with the soil $\mathrm{N}$ concentration, fungal DNA and ammonia oxidisers, and negatively $(P<0.05)$ correlated with the soil $\mathrm{WC}, \mathrm{C} / \mathrm{N}$ ratio and $\mathrm{qCO}_{2}$.

\section{Discussion}

\section{Differences between burnt and unburnt soils}

The results showed that wildfire caused significant changes in soil physical, chemical and biological characteristics persisting up to a year. 


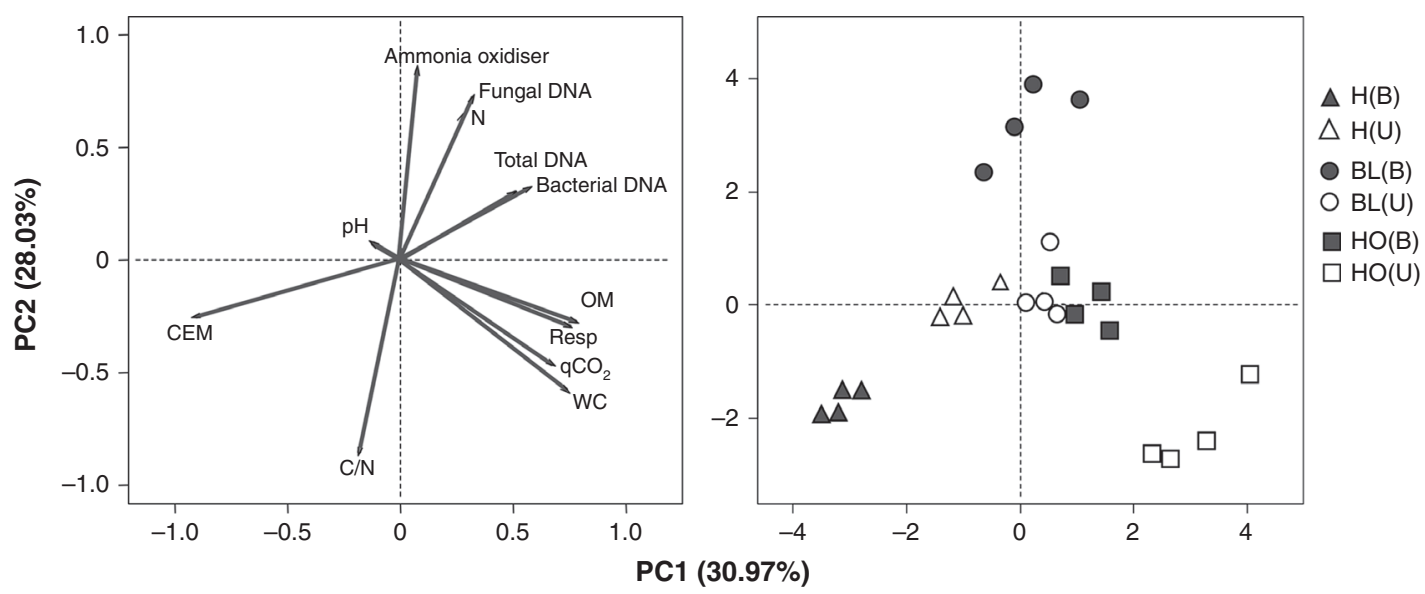

Fig. 4. Results of PCA (principal component analysis). Spatial distribution of the burnt (B) and unburnt (U) soils under different plant types ( $\mathrm{H}$, herbaceous; $\mathrm{BL}$, black locust; $\mathrm{HO}$, holm oak) according to soil parameters ( $\mathrm{pH}$; $\mathrm{WC}$, water content; OM, organic matter; $\mathrm{N}$, nitrogen content; $\mathrm{C} / \mathrm{N}$ ratio; total DNA; fungal DNA; bacterial DNA; ammonia oxidisers; Resp, microbial respiration; $\mathrm{qCO}_{2}$, metabolic quotient; CEM, coefficient of endogenous mineralisation). Grey shapes represent burnt and white shapes represent unburnt sites; symbols indicate plant types.

In particular, the reduction in soil OM (and consequently the significant decrease in WC observed in burnt soil) was a result of the destruction of the organic layer by fire, which decreases water permeation and soil storage capacity (Imeson et al. 1992; Rastad 2009). Conversely, fire affected the quality of organic matter, leaving the most recalcitrant fraction in the burnt soil, as shown by the highest $\mathrm{C} / \mathrm{N}$ ratio (González-Pérez et al. 2004).

Although wildfire seems not to directly affect the microbial abundance (defined as the total, fungal, eubacterial and ammonia-oxidising bacterial abundance), a significantly lower $\mathrm{qCO}_{2}$ and higher CEM were observed in burnt than in unburnt soils. After fires, a large proportion of the soil microbial biomass can show high energy consumption, suggesting the presence of highly efficient decomposers and less efficient producers (Wüthrich et al. 2002).

Due to the different plant typologies, the wide heterogeneity of sites affected the soil characteristics and, consequently, the fire impact on the investigated soils. The site distribution in the PC space also showed that within the same plant type, wildfires caused noticeable differences in soil characteristics, such as $\mathrm{WC}, \mathrm{C} / \mathrm{N}$ ratio, $\mathrm{N}$, fungal DNA and ammonia oxidiser abundance and $\mathrm{qCO}_{2}$, factors related to the $\mathrm{PC} 2$ axis.

The differences between unburnt and burnt soils varied between soils covered by herbaceous plants and trees and soils covered by black locusts and holm oaks. In particular, N, fungal DNA and ammonia oxidisers were less abundant in burnt than in unburnt soils covered by herbaceous materials, and the $\mathrm{C} / \mathrm{N}$ ratio was higher, whereas the same soil characteristics showed an opposite trend for burnt soils covered by black locust and holm oak.

Plant typology affected soil physico-chemical and biological characteristics

In soils covered by trees, the statistically higher OM values were a result of the higher plant productivity and, consequently, the large amount of litter fall (De Marco et al. 2008), which in turn affected the soil WC (Reicosky 2005). These conditions fit with those reported by Degens et al. (2000) and Riveros-Iregui et al. (2007), who highlighted that soil moisture and organic matter content are key drivers of soil microbial community activity and composition. The dominance of herbaceous species in Mediterranean systems is always related to low organic $\mathrm{C}$ and $\mathrm{N}$ contents, and to the decrease in specific enzymatic activities that negatively affect soil fertility (López-Poma and Bautista 2014; Mayor et al. 2016). Herbs and grasses have a lower capacity to trap resources and are considered source areas, in contrast to shrub and tree sites, which are known as sinks owing to their high soil carbon storage.

Therefore, in the investigated area, soils covered by trees, despite exhibiting the highest amount of total and bacterial DNA, showed the lowest microbial mineralisation activity (i.e. CEM), likely because of the scarce litter decomposability corroborated by the higher $\mathrm{C} / \mathrm{N}$ ratio. These results were confirmed by the greater stability of soil organic matter occurring in shrub and tree sites compared with gap areas in Mediterranean ecosystems (De Marco et al. 2008).

The PCA highlighted the role of plant type in driving soil characteristics, especially in terms of $\mathrm{OM}, \mathrm{WC}$, total and bacterial DNA, Resp, $\mathrm{qCO}_{2}$ and CEM, which were higher in soils covered by black locusts and holm oaks, with the exception of CEM. These factors, which were significantly related to PC1 and were involved in the distribution of sites along this axis, distinguished the soils covered by herbaceous plants from those covered by trees, both black locusts and holm oaks.

Specific responses of soil characteristics to fire related to the distinct plant type

The comparison between burnt and unburnt soils showed the effects of fire 1 year after a disturbance, but also highlighted the specific responses determined by the different types of plant cover.

In all the burnt soils, a significant decrease in WC was observed, which was particularly amplified in soils covered by black locusts and holm oaks, where a greater loss of organic 
matter occurred. Therefore, after fire, hydrophobic components that have been volatilised as a result of combustion can reprecipitate on the soil, increasing water repellency. This phenomenon is particularly evident in holm oak forests, where fast ponding and greater runoff rates are usually observed (Cerda et al. 1998).

According to the different plant typologies, the wildfire affected not only the amount of OM but also its quality, leaving the most recalcitrant fraction in soils covered by herbaceous soils, as shown by the significantly higher values of the $\mathrm{C} / \mathrm{N}$ ratio compared with those in soils covered by trees (Certini et al. 2011; Yanardağ et al. 2017). A lower capacity for storing $\mathrm{C}$ after fires in shrubs than pine and in herbaceous plants than shrubs was reported by Kaye et al. (2010) and De Marco et al. (2008), respectively, owing to differences in litter degradability. Changes in organic matter recalcitrance could also be related to the $\mathrm{qCO}_{2}$ values, according to the results of Mataix-Solera et al. (2002), who found lower values of $\mathrm{qCO}_{2}$ and a higher $\mathrm{C} / \mathrm{N}$ ratio in burnt soil compared with unburnt soil 11 years after a wildfire. Despite the increase in the complexity of organic matter and the decrease in $\mathrm{qCO}_{2}$, burnt soils covered by herbaceous plants showed a significant increase in mineralisation, likely owing to the use of more energy for organic carbon consumption than for biomass production. These findings agree with those reported by Fierro et al. (2007), who found biological stimulation of mineralisation and $\mathrm{C}$ loss from soils in Mediterranean low maquis shrubland caused by fire. In this way, soil in herbaceous or shrub areas also loses $\mathrm{C}$ for a long time after fire, and these effects could result in more fertility losses (Mayor et al. 2016).

In addition, in soils covered by herbaceous plants, the lack of statistically significant differences in total and bacterial DNA between burnt and unburnt soils seems to confirm the limited use of energy in biomass production.

The wildfire also induced significantly higher values of total, fungal and bacterial DNA in tree-covered soils than in herbaceous plant-covered soils. Regarding the tree-covered soils, those under holm oaks were characterised by a marked increase in the fungal community.

In particular, under holm oaks, a shift in bacterial and fungal amounts was observed. The bacterial DNA was statistically lower in burnt soils, whereas the fungal DNA was statistically higher. The observed shift in bacterial and fungal amounts was likely associated with the great water loss in soils covered by holm oak. Fungi and bacteria have been shown to respond differently to water availability (de Vries et al. 2006; Bapiri et al. 2010), and fungi may be more tolerant to reduced soil water content (Manzoni et al. 2012; Guhr et al. 2015).

Additionally, specific responses to the wildfire were observed in the soil N content, which showed the highest values in the burnt soils under black locust, and the lowest under herbaceous plants. The availability of this nutrient is generally increased by combustion and is strictly dependent upon the types of burnt tree species (Kutiel 1994). The key role of black locust in regulating the $\mathrm{N}$ cycle is well known because of its association with $\mathrm{N}_{2}$ fixers and in influencing $\mathrm{N}$ losses due to fire, which are particularly frequent in these forest types (De Marco et al. 2008, 2013). After the fire, the amount of ammonia oxidisers was higher mainly in soils dominated by black locust, probably owing to the greater $\mathrm{N}$ demand by black locusts, which have faster productivity after fire (Prieto-Fernández et al. 2004; Yeager et al. 2005; Smithwick et al. 2012).

\section{Conclusions}

Our findings suggest that the first year after a fire is a critical time period for soil restoration in the Mediterranean area because the soil's chemical, physical and biological characteristics have been greatly altered. The novelty of this research is the simultaneous investigation of burnt and unburnt soils under three different plant types, and the results highlight how fire effects depend on the heterogeneity of the Mediterranean environment. The burnt soils had lower organic matter and water contents than did the unburnt soils, especially those under trees, owing to the higher productivity and greater runoff rates than those under herbaceous plants. Conversely, in burnt soils covered by herbaceous plants, the observed highest mineralisation seemed to be related to the use of energy by microorganisms, which used more energy to consume organic carbon than to produce biomass. Additionally, fire caused a shift in the microbial community composition, enhancing the fungal abundance rather than the bacterial abundance in soil covered by holm oak, and favouring ammonia oxidisers, mainly in soil covered by black locust, which also showed the highest $\mathrm{N}$ content.

Moreover, our study confirmed that the soil microbial community quickly reacts to disturbances from fire; additionally, abundance and activity are useful indicators to evaluate the reestablishment of soil functions and ecosystem recovery. In particular, the soils covered by herbaceous species seemed to be more sensitive to overall variations owing to fire, and less able to restore their functionality compared with soils covered by trees (i.e. black locust and holm oak), probably because of their lowest microbial abundance and higher $\mathrm{C}$ losses.

\section{Conflicts of interest}

The authors declare that they have no conflicts of interest.

\section{Acknowledgments}

We gratefully acknowledge the Forest Service for allowing the authors to access the field sites and for logistical support. The authors thank native English-speaking editors at Springer Nature Author Services for English revision. This project was financed by the Vesuvius National Park and the Department of Biology of the University of Naples Federico II (Project: 'Impatto antropico da pressione turistica nelle aree protette: interferenze su territorio e biodiversità' - CUP: E65J13000030001 - financed by The Ministry for the Environment and for the Care of the Land and the Sea Direttiva Conservazione della Biodiversità n. 5135, 11.03.2015 and n. 24444 del 17.10.2018).

\section{References}

Anderson TH, Domsch KH (1978) A physiological method for the quantitative measurements of microbial biomass in soil. Soil Biology \& Biochemistry 10, 215-221. doi:10.1016/0038-0717(78)90099-8

Arias ME, González-Pérez JA, González-Vila FJ, Ball AS (2005) Soil health - a new challenge for microbiologists and chemists. International Microbiology 8, 13-21.

Bapiri A, Bååth E, Rousk J (2010) Drying-rewetting cycles affect fungal and bacterial growth differently in an arable soil. Microbial Ecology 60, 419-428. doi:10.1007/S00248-010-9723-5 
Bouchez T, Blieux AL, Dequiedt S, Domaizon I, Dufresne A, Ferreira S, Godon JJ, Hellal J, Joulian C, Quaiser A, Martin-Laurent F, Mauffret A, Monier JM, Peyret P, Schmitt-Koplin P, Sibourg O, D'oiron E, Bispo A, Deportes I, Grand C, Cuny P, Ranjard PA (2016) Molecular microbiology methods for environmental diagnosis. Environmental Chemistry Letters 14, 423-441. doi:10.1007/S10311-016-0581-3

Ceccherini MT, Ascher J, Pietramellara G, Mocali S, Viti C, Nannipieri P (2007) The effect of pharmaceutical waste-fungal biomass, treated to degrade DNA, on the composition of eubacterial and ammonia oxidizing populations of soil. Biology and Fertility of Soils 44, 299-306. doi:10. 1007/S00374-007-0204-Z

Cerda A, Schnabel S, Ceballos A, Gomez-Amelia D (1998) Soil hydrological response under simulated rainfall in the Dehesa land system (Extremadura, SW Spain) under drought conditions. Earth Surface Processes and Landforms 23, 195-209. doi:10.1002/(SICI)10969837(199803)23:3<195::AID-ESP830>3.0.CO;2-I

Certini G (2005) Effects of fire on properties of forest soils: a review. Oecologia 143, 1-10. doi:10.1007/S00442-004-1788-8

Certini G, Nocentini C, Knicker H, Arfaioli P, Rumpel C (2011) Wildfire effects on soil organic matter quantity and quality in two fire-prone Mediterranean pine forests. Geoderma 167-168, 148-155. doi:10.1016/ J.GEODERMA.2011.09.005

D’Ascoli R, Rutigliano FA, De Pascale RA, Gentile A, Virzo De Santo A (2005) Functional diversity of microbial community in Mediterranean maquis soils as affected by fires. International Journal of Wildland Fire 14, 355-363. doi:10.1071/WF05032

De Marco A, Meola A, Esposito F, Virzo De Santo A (2008) Productivity and modifications of ecosystem processes in gaps of a low Macchia in southern Italy. Web Ecology 8, 55-66. doi:10.5194/WE-8-55-2008

De Marco A, Esposito F, Berg B, Giordano M, Virzo De Santo A (2013) Soil $\mathrm{C}$ and $\mathrm{N}$ sequestration in organic and mineral layers of two coeval forest stands implanted on pyroclastic material (Mount Vesuvius, South Italy). Geoderma 209-210, 128-135. doi:10.1016/J.GEODERMA. 2013.06.011

de Vries FT, Hoffland E, van Eekeren N, Brussaard L, Bloem J (2006) Fungal/bacterial ratios in grasslands with contrasting nitrogen management. Soil Biology \& Biochemistry 38, 2092-2103. doi:10.1016/ J.SOILBIO.2006.01.008

Degens BP, Schipper LA, Sparling GP, Vojvodic-Vukovic M (2000) Decreases in organic $\mathrm{C}$ reserves in soils can reduce the catabolic diversity of soil microbial communities. Soil Biology \& Biochemistry 32, 189-196. doi:10.1016/S0038-0717(99)00141-8

Di Gennaro A (Ed.) (2002) 'I sistemi di terre della Campania.' (Assessorato Regionale alla Ricerca Scientifica: Firenze) [In Italian]

Fierro A, Rutigliano AF, De Marco A, Castaldi S, Virzo De Santo A (2007) Post-fire stimulation of soil biogenic emission of $\mathrm{CO}_{2}$ in a sandy soil of a Mediterranean shrubland. International Journal of Wildland Fire 16, 573-583. doi:10.1071/WF06114

Froment A (1972) Soil respiration in a mixed oak forest. Oikos 23, 273-277. doi: $10.2307 / 3543417$

Ganteaume A, Camia A, Jappiot M, San-Miguel-Ayanz J, Long-Fournel M, Lampin C (2013) A review of the main driving factors of forest fire ignition over Europe. Environmental Management 51, 651-662. doi:10. 1007/S00267-012-9961-Z

Gil-Tena A, Aquilué N, Duane A, De Cáceres M, Brotons L (2016) Mediterranean fire regime effects on pine-oak forest landscape mosaics under global change in NE Spain. European Journal of Forest Research 135, 403-416. doi:10.1007/S10342-016-0943-1

Goberna M, García C, Insam H, Hernández MT, Verdú M (2012) Burning fire-prone Mediterranean shrublands: immediate changes in soil microbial community structure and ecosystem functions. Microbial Ecology 64, 242-255. doi:10.1007/S00248-011-9995-4

Gómez-Rey MX, Couto-Vázquez A, García-Marco S, González-Prieto SJ (2013) Impact of fire and post-fire management techniques on soil chemical properties. Geoderma 195-196, 155-164. doi:10.1016/ J.GEODERMA.2012.12.005

González-Pérez JA, González-Vila FJ, Almendros G, Knicker H (2004) The effect of fire on soil organic matter - a review. Environment International 30, 855-870. doi:10.1016/J.ENVINT.2004.02.003

Guhr A, Borken W, Spohn M, Matzner E (2015) Redistribution of soil water by a saprotrophic fungus enhances carbon mineralization. Proceedings of the National Academy of Sciences of the United States of America 112, 14647-14651. doi:10.1073/PNAS.1514435112

Hastings RC, Ceccherini MT, Miclaus N, Saunders JR, Bazzicalupo M, McCarthy AJ (1997) Direct molecular biological analysis of ammonia oxidising bacteria populations in cultivated soil plots treated with swine manure. FEMS Microbiology Ecology 23, 45-54. doi:10.1111/J.15746941.1997.TB00390.X

Imeson AC, Verstraten JM, van Mulligan EJ, Sevink J (1992) The effects of fire and water repellency on infiltration and runoff under Mediterranean type forest. Catena 19, 345-361. doi:10.1016/0341-8162(92)90008-Y

Insam H, Haselwandter K (1989) Metabolic quotient of the soil microflora in relation to plant succession. Oecologia 79, 174-178. doi:10.1007/ BF00388474

Kaye JP, Romanyà J, Vallejo VR (2010) Plant and soil carbon accumulation following fire in Mediterranean woodlands in Spain. Oecologia 164, 533-543. doi:10.1007/S00442-010-1659-4

Kutiel P (1994) Fire and ecosystem heterogeneity: a mediterranean case of study. Earth Surface Processes and Landforms 19, 187-194. doi:10. 1002/ESP.3290190209

López-Poma R, Bautista S (2014) Plant regeneration functional groups modulate the response to fire of soil enzyme activities in a Mediterranean shrubland. Soil Biology \& Biochemistry 79, 5-13. doi:10.1016/J.SOILBIO. 2014.08.016

Mabuhay JA, Isagi J, Nakagoshi N (2006) Wildfire effects on microbial biomass and diversity in pine forests at three topographic positions. Ecological Research 21, 54-63. doi:10.1007/S11284-005-0094-1

Manzoni S, Schimel JP, Porporato A (2012) Physical vs. physiological controls on water-stress response in soil microbial communities. Ecology 93, 930-938. doi:10.1890/11-0026.1

Martin DA, Moody JA (2001) Comparison of soil infiltration rates in burned and unburned mountainous watersheds. Hydrological Processes 15, 2893-2903. doi:10.1002/HYP.380

Mataix-Solera J, Gómez I, Navarro-Pedreño J, Guerrero C, Moral R (2002) Soil organic matter and aggregates affected by wildfire in a Pinus halepensis forest in a mediterranean environment. International Journal of Wildland Fire 11, 107-114. doi:10.1071/WF02020

Mayor AG, Valdecantos A, Vallejo VR, Keizer JJ, Bloema J, Baeza J, González-Pelayo O, Machado AI, de Ruiter PC (2016) Fire-induced pine woodland to shrubland transitions in southern Europe may promote shifts in soil fertility. The Science of the Total Environment 573, 12321241. doi:10.1016/J.SCITOTENV.2016.03.243

Memoli V, Eymar E, García-Delgado C, Esposito F, Santorufo L, De Marco A, Barile R, Maisto G (2018) Total and fraction content of elements in volcanic soil: natural or anthropogenic derivation. The Science of the Total Environment 625, 16-26. doi:10.1016/J.SCITOTENV.2017. 12.223

Nannipieri P, Ascher J, Ceccherini MT, Landi L, Pietramellara G, Renella G (2003) Microbial diversity and soil functions. European Journal of Soil Science 54, 655-670. doi:10.1046/J.1351-0754.2003.0556.X

Panico SC, Memoli V, Esposito F, Maisto G, De Marco A (2018) Plant cover and management practices as drivers of soil quality. Applied Soil Ecology 129, 34-42. doi:10.1016/J.APSOIL.2018.05.001

Pribyl DW (2010) A critical review of the conventional SOC to SOM conversion factor. Geoderma 156, 75-83. doi:10.1016/J.GEODERMA. 2010.02.003

Prieto-Fernández A, Carballas M, Carballas T (2004) Inorganic and organic $\mathrm{N}$ pools in soils burned or heated: immediate alterations and 
evolution after forest wildfires. Geoderma 121, 291-306. doi:10.1016/ J.GEODERMA.2003.11.016

R Core Team (2016). R: a language and environment for statistical computing. R Foundation for Statistical Computing, Vienna. http:// www.R-project.org.

Raison RJ, Khanna PK, Jacobsen KLS, Romanya J, Serrasolses I (2009) Effects of fire on forest nutrient cycles. In 'Fire effects on soils and restoration strategies'. (Eds A Cerdà, PR Robichaud) pp. 225-256. (Science Publishers: USA).

Rastad H (2009). Study of fire effect on soil physical and chemical properties and regeneration at conifer stands of Guilan provience. Case study Siahkal forests. M.Sc. Thesis, University of Guilan, Rasht, Iran

Reicosky DC (2005) Alternatives to mitigate the greenhouse effect: emission control by carbon sequestration. In 'Simpósio sobre Plantio direto e Meio ambiente; Seqüestro de carbono e qualidade da agua, 18-20 de Maio 2005, Foz do Iguaçu, Brazil'. pp. 20-28.

Riveros-Iregui DA, Emanuel RE, Muth DJ, McGlynn BL, Epstein HE, Welsch DL, Wraith JM (2007) Diurnal hysteresis between soil $\mathrm{CO}_{2}$ and soil temperature is controlled by soil water content. Geophysical Research Letters 34, L17404. doi:10.1029/2007GL030938

Rodríguez J, González-Pérez JA, Turmero A, Hernández M, Ball AS, González-Vila FJ, Arias ME (2017) Wildfire effects on the microbial activity and diversity in a Mediterranean forest soil. Catena 158, 82-88. doi:10.1016/J.CATENA.2017.06.018

Rutigliano FA, D’Ascoli R, De Marco A, De Santo AV (2002) Soil microbial community as influenced by experimental fires of different intensities. In 'Fire and biological processes'. (Eds L Trabaud, R Prodon) pp 137-150. (Backhuys Publishers: Leiden)

Rutigliano FA, De Marco A, D’Ascoli R, Castaldi S, Gentile A, Virzo De Santo A (2007) Impact of fire on fungal abundance and microbial efficiency in $\mathrm{C}$ assimilation and mineralisation in a Mediterranean maquis soil. Biology and Fertility of Soils 44, 377-381. doi:10.1007 S00374-007-0214-X

San-Miguel-Ayanz J, Camia A (2010) Forest fires. In 'Mapping the impacts of natural hazards and technological accidents in Europe an overview of the last decade'. EEA Technical Report No 13/2010. pp. 49-55, Publications Office of the European Union. (Luxembourg)
Smithwick EAH, Naithani KJ, Balser TC, Romme WH, Turner MG (2012) Post-fire spatial patterns of soil nitrogen mineralization and microbial abundance. PLoS One 7, e50597. doi:10.1371/JOURNAL.PONE. 0050597

Sparling GP (1995) The soil biomass. In 'Soil organic matter and biological activity'. (Eds D Vaughan, RE Malcolm) pp. 223-262. (Nijhoff/Junk: Dordrecht)

Thom D, Seidi R (2016) Natural disturbance impacts on ecosystem services and biodiversity in temperate and boreal forests. Biological Reviews of the Cambridge Philosophical Society 91, 760-781. doi:10.1111/BRV.12193

Vega JA, Fontúrbel T, Merino A, Fernández C, Ferreiro A, Jiménez E (2013) Testing the suitability of visual indicators of soil burn severity to reflect changes in soil chemical and microbial properties in pine stands and shrublands. Plant and Soil 369, 73-91. doi:10.1007/S11104-012-1532-9

Vesterdal L, Elberling B, Christiansen JR, Callesen I, Schmidt IK (2012) Soil respiration and rates of soil carbon turnover differ among six common European tree species. Forest Ecology and Management 264, 185-196. doi:10.1016/J.FORECO.2011.10.009

Virzo De Santo A, Rutigliano FA, Berg B, Fioretto A, Puppi G, Alfani A (2002) Fungal mycelium and decomposition of needle litter in three contrasting coniferous forests. Acta Oecologica 23, 247-259. doi:10. 1016/S1146-609X(02)01155-4

Wolfe BE, Klironomos JN (2005) Breaking new ground: soil communities and exotic plant invasion. Bioscience 55, 477-487. doi:10.1641/00063568(2005)055[0477:BNGSCA]2.0.CO;2

Wüthrich C, Schaub D, Weber M, Marxer P, Conedera M (2002) Soil respiration and soil microbial biomass after fire in a sweet chestnut forest in southern Switzerland. Catena 48, 201-215. doi:10.1016/S03418162(01)00191-6

Yanardağ IH, Zornoza R, Bastida F, Buyukkilic-Yanardag A, Garcia C, Faz A (2017) Native soil organic matter conditions the response of microbial communities to organic inputs with different stability. Geoderma 295, 1-9. doi:10.1016/J.GEODERMA.2017.02.008

Yeager CM, Northup DE, Grow CC, Barns SM, Kuske CR (2005) Changes in nitrogen-fixing and ammonia-oxidizing bacterial communities in soil of a mixed conifer forest after wildfire. Applied and Environmental Microbiology 71, 2713-2722. doi:10.1128/AEM.71.5.2713-2722.2005 